DOI: https://doi.org/10.31933/jemsi.v2i5

Received: 30 Maret 2021, Revised: 15 Mei 2021, Publish: 22 Juni 2021

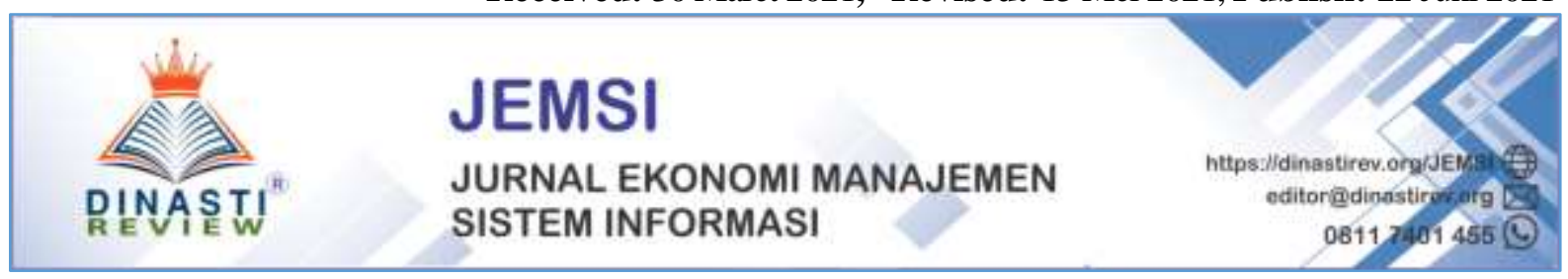

\title{
DAMPAK PERUBAHAN KURS RUPIAH, LAJU INFLASI DAN FLUKTUASI KURS VALUTA ASING PADA PEFORMA INDEK HARGA SAHAM SYARIAH INDONESIA (ISSI)
}

\author{
Annisa Elly Octaviani ${ }^{1}$, Hilda Mary ${ }^{2}$, Laynita Sari $^{3}$, Elfiswandi Elfiswandi ${ }^{4}$, Zefriyenni \\ Zefriyenni ${ }^{5}$ \\ 1) Universitas Putra Indonesia YPTK, Padang, Indonesia \\ 2) Universitas Putra Indonesia YPTK, Padang, Indonesia, hildamary@ upiyptk.ac.id \\ 3) Universitas Putra Indonesia YPTK, Padang, Indonesia \\ 4) Universitas Putra Indonesia YPTK, Padang, Indonesia \\ ${ }^{5)}$ STIE KBP, Padang Indonesia
}

\section{Koresponen: Hilda Mary}

\begin{abstract}
Abstrak: Penelitian ini bertujuan untuk mengetahui seberapa besar pengaruh kurs rupiah, laju inflasi dan kurs valuta asing pada peforma indeks harga saham syariah Indonesia dengan kajian Jakarta Islamic indek (JII). Metode pengumpulan sampel dengan menggunakan purposive sampling, dengan jumlah sampel sebanyak 27 perusahaan yang terdaftar di Jakarta Islamic indek. Metode analisis yang digunakan adalah adalah regresi linear berganda dan menggunakan data runtut waktu (Time Series) dengan pendekatan Error Correction Model (ECM). Hasil penelitian yang didapatkan berdasarkan Uji Parsial (Uji t) diperoleh : (a) Tidak terdapat pengaruh dan signifikan variabel Perubahan kurs rupiah terhadap Harga saham syariah (b) Tidak terdapat pengaruh dan signifikan variabel Laju inflasi terhadap Harga saham syariah (c) Tidak terdapat pengaruh dan signifikan variabel Fluktuasi kurs valuta asing terhadap Harga saham syariah (d) Terdapat pengaruh dan signifikan variabel Perubahan kurs rupiah, Laju inflasi dan Fluktuasi kurs valuta asing terhadap Harga saham syariah.
\end{abstract}

Kata Kunci: Kurs Rupiah, Inflasi, Kurs Valuta Asing dan Harga Saham Syariah.

\section{PENDAHULUAN}

Dalam rangka mencapai profit atau laba yang maksimal perusahaan harus meningkatkan kesejahteraan pemegang saham Peforma indek harga saham dapat ditingkatkam melalui peningkatan kemakmuran pemegang saham. Kesejahteraan pemegang saham mampu dijadikan sebagai gambaran dari nilai suksesnya peforma sebuah indek. Peforma indek harga saham sangat penting bagi perusahaan karena peforma indek harga saham menunjukkan seberapa baik kinerja perusahaan tersebut. Bursa Efek Indonesia (BEI), telah membuat pengelompokan terhadap saham-saham yang terdaftar di (BEI), salah satunya adalah saham perusahaan Syariah Indonesia (ISSI)

Konstituen ISSI adalah semua saham syariah yang tercatat di BEI dan masuk kedalam Daftar Efek Syariah (DES) yang diterbitkan oleh OJK. Konstituen ISSI diseleksi ulang 
sebanyak 2 kali dalam setahun, setiap bulan Mei dan melakukan perhitungan bulan di bulan November. Metode perhitungan ISSI mengikuti metode perhitungan saham indeks saham BEI lainnya (Muchtar, 2019). Indeks Saham Syariah Indonesia (ISSI) merupakan indeks saham yang mencerminkan secara keseluruhan saham syariah yang tercatat di BEI. Perusahaan yang tercatat di Indeks Saham Syariah Indonesia harus memenuhu rasio - rasio keuangan seperti total utang yang berbasis bunga dibandingkan dengan total aset tidak lebih dari $45 \%$ (empat puluh lima persen) dan total pendapatan tidak halal lainnya dibandingkan dengan total pendapatan usaha dan pendapatan lain - lain tidak lebih dari $10 \%$.

Performa indeks saham syariah dipengaruhi oleh beberapa faktor, antara lain faktor perubahan kurs rupiah,laju inflasi dan fluktuasi kurs valuta asing. Kurs rupiah adalah harga dari mata uang suatu negara dalam harga mata uang dengan negara lainnya. Dan Kurs valuta asing merupakan harga suatu mata uang terhadap mata uang lainnya yang mencerminkan keseimbangan permintaan dan penawaran terhadap mata uang dalam negeri.

\section{KAJIAN PUSTAKA}

Indeks Saham Syariah Indonesia (ISSI) merupakan salah satu indeks saham di Indonesia yang menghitung indeks harga rata-rata saham untu jenis kegiatan usaha yang memenuhi kriteria syariah. Saham-saham yang masuk dalam indeks syariah adalah emiten yang kegiatan usahanya tidak bertentangan dengan prinsip syariah.

Menurut (Rifai, 2017) nilai tukar mata uang merupakan perbandingan nilai dua mata uang yang berbeda atau disebut kurs. Sedangkan kurs rupiah (nilai tukar) sebagai harga mata uang untuk suatu nrgara ke negara lain. Sehingga nilai tukar rupiah dapat diartikan sebagai harga jual atau harga beli mata uang rupiah terhadap mata uang selain rupiah. Menurut (Sukirno, 2015) kurs rupiah (nilai tukar) sebagai harga mata uang untuk suatu nrgara ke negara lain. Sehingga nilai tukar rupiah dapat diartikan sebagai harga jual atau harga beli mata uang rupiah terhadap mata uang selain rupiah.

Menurut (Fahmi, 2012) nilai tukar atau foreign exchange rate adalah perubahan nilai mata uang suatu negara saat dikonversikan ke dalam mata uang dari negara lain. Dalam hal ini yang dimaksud adalah mata uang rupiah terhadap mata uang asing. Karena nilai tukar ini mencakup dua mata uang dari dua negara yang berbeda,maka titik keseimbangannya ditentukan berdasarkan sisi penawaran dan permintaan dari kedua mata uang tersebut.

Inflasi adalah keadaan yang menunjukkan kenaikan harga - harga umum secara terus menerus. Perkataan terus menerus menunjukkan bahwa kenaikan harga walaupun melonjak tajam tapi sekali saja tidakdikategorika sebagai inflasi. Definisi lain dari inflasi adalah keadaan diaman terjadi kelebihan permintaan (excess demand) terhadap barang dan jasa secara keseluruhan (Budiono, 2012).

Kurs valas dapat didefinisikan sebagai satuan valuta ( mata uang ) asing apabila ditukar dengan mata uang dalam negeri atau harga mata uang negara asing dalam satuan mata uang domestic (Yahya, 2014). Sedangkan menurut (Putri, 2019) Valuta asing dapat diartikan sebagai mata uang yang dikeluarkan dan digunakan sebagai alat pembayaran yang sah dinegara lain. Didalam hukum ekonomi bila terdapat suatu barang dan keduanya bertmu maka akan terbentuk dua hal yaitu pasar dan harga. Begitu juga halnya dengan valuta asing, bila permintaan terhadap valuta tertentu bertemu dengan penawaran valuta yang sama maka akan terbentuk pasar dan harga

\section{Pengembangan Hipotesis}


Dalam pengembangan hipotesis pada Harga Indeks Saham Syariah Yang Terdaftar di BEI Periode 2015-2019 antara lain:

H1 : Diduga terdapat pengaruh perubahan kurs rupiah (X1) secara parsial terhadap Indeks Saham Syariah Indonesia (Y)

H2 : Diduga terdapat pengaruh Inflasi (X2) secara parsial terhadap Indeks Saham Syariah Indonesia (Y)

H3 : Diduga terdapat pengaruh fluktuasi kurs valuta asing (X1) secara parsial terhadap Indeks Saham Syariah Indonesia (Y)

H4 : Diduga perubahan kurs rupiah (X1), inflasi (X2), dan Fluktuasi Kurs Valuta Asing (X3) secara simultan signifikan pengaruhnya terhadap Indeks Saham Syariah.

\section{METODE PENELITIAN}

Dalam penelitian ini yang menjadi populasi adalah 30 perusahaan yang terdaftar di Jakarta Islamic Index (JII) yang terdaftar di Bursa Efek Indonesia (BEI) tahun 2015-2019. Dalam pengambilan sampel dilakukan dengan Purposive Sampling yaitu pengambilan kriteria sampel sesuai dengan penelitian yang akan dilakukan.

Metode estimasi yang digunakan dalam penelitian ini adalah regresilinear berganda untuk mengkaji hubungan dua atau lebih variable bebas terhadap variabel terikat dan menggunakan data runtut waktu (Time Series) dengan pendekatan Error Correction Model (ECM). Dalam penelitian ini, digunakan alat bantu untuk mempermudah pengolahan data yaitu dengan menggunakan software Eviews 9.0.

\section{HASIL DAN PEMBAHASAN}

\section{Hasil Uji Statistik Deskriptif}

Tabel 1. Hasil uji statistik deskriptif

\begin{tabular}{|l|c|c|c|c|}
\hline & $\begin{array}{c}\text { HARGA_SAHAM } \\
\text { SYARIAH }\end{array}$ & KURS_RUPIAH & INFLASI & $\begin{array}{c}\text { KURS_VALUTA__ } \\
\text { ASING }\end{array}$ \\
\hline Mean & 0.003 & 13695.51 & 3.989 & 0.002 \\
\hline Maximum & 0.121 & 15227.00 & 7.260 & 0.078 \\
\hline Minimum & -0.087 & 12625.00 & 2.480 & -0.069 \\
\hline Std. Dev. & 0.043 & 554.7277 & 1.372 & 0.023 \\
\hline Observations & 60 & 60 & 60 & 60 \\
\hline
\end{tabular}

Berdasarkan Tabel diatas menjelaskan secara deskriptif variabel-variabel dalam penelitian ini. Variabel Harga saham syariah yang terjadi rata-ratanya adalah sebesar 0,003 dengan standar deviasi sebesar 0,043 nilai maksimum sebesar -0,087 dan nilai minimum sebesar 0,121. Variabel Perubahan kurs rupiah yang terjadi rata-ratanya adalah sebesar 13.695,51 dengan standar deviasi 554,72, nilai maksimum sebesar 14.227 dan nilai minimum sebesar 12.625, Variabel Laju inflasi yang terjadi rata-ratanya adalah sebesar 3,989 dengan standar deviasi 1,372, nilai maksimum sebesar 7,26 dan nilai minimum sebesar 2,48 dan Variabel Fluktuasi kurs valuta asing yang terjadi rata-ratanya adalah sebesar 0,002132 dengan standar deviasi 0,023 , nilai maksimum sebesar 0,078 dan nilai minimum sebesar 0,069 . 


\section{Uji Normalitas}

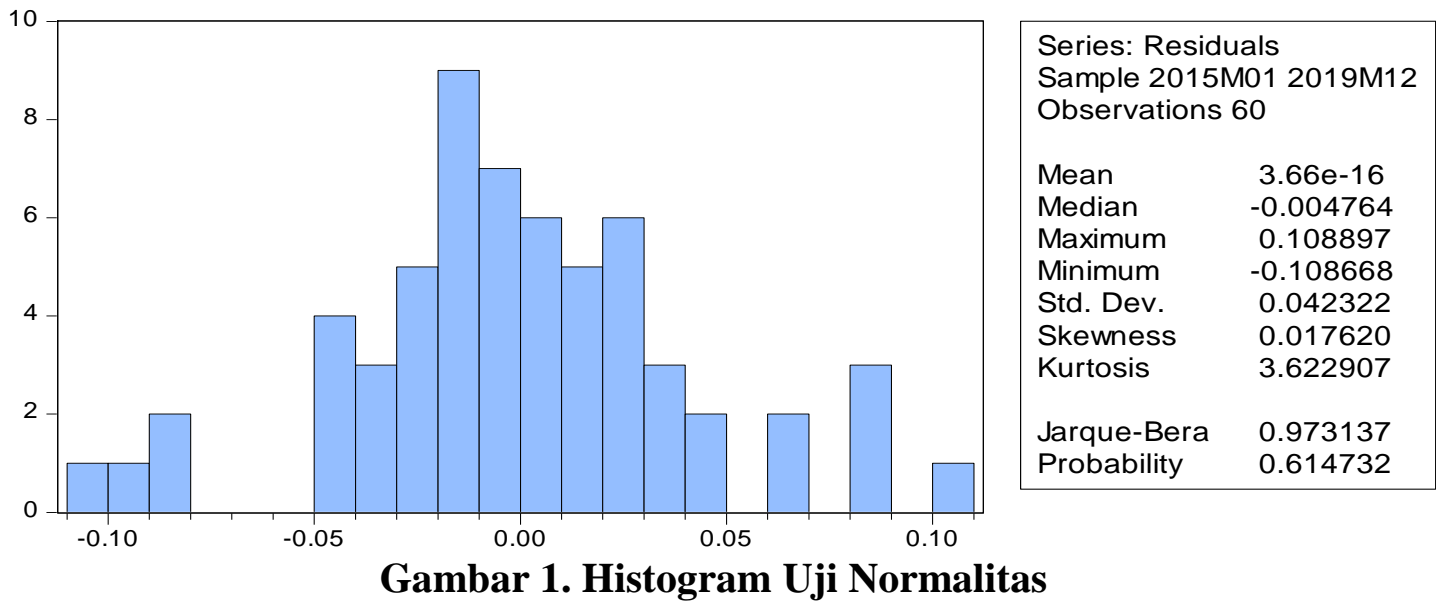

Berdasarkan hasil uji Jarque-Bera pada tabel di atas dapat diketahui bahwa nilai Jarque-Bera adalah sebesar 0,973 dengan probabilitas 0,614. Karena nilai probabilitas $0,614>0,05$ maka dapat dikatakan bahwa residual dalam model penelitian ini telah berdistribusi normal.

\section{Uji Multikolinearitas}

Tabel 2. Hasil Uji Multikolinearitas (Corelation Matrix)

\begin{tabular}{cccc}
\hline \hline Variable & $\begin{array}{c}\text { Coefficient } \\
\text { Variance }\end{array}$ & $\begin{array}{c}\text { Uncentered } \\
\text { VIF }\end{array}$ & $\begin{array}{c}\text { Centered } \\
\text { VIF }\end{array}$ \\
\hline \hline LOGKURSRUPAIH & 0.024 & 69956.77 & 1.221 \\
INFLASI & 2.022 & 11.393 & 1.187 \\
KURS_VALUTA_ASI & & & 1.119 \\
NG & 0.062 & 1.128 & NA \\
C & 2.219 & 70580.30 & \\
\hline \hline
\end{tabular}

Berdasarkan tabel dapat dilihat bahwa Centered VIF. Nilai VIF untuk variabel Perubahan kurs rupiah sebesar 1,221, variabel Laju inflasi memiliki nilai VIF sebesar 1,187 dan variabel Fluktuasi kurs valuta asing memiliki nilai VIF sebesar 1,119. Karena nilai VIF dari ketiga variabel tidak ada yang lebih besar dari 10 atau 5 (banyak buku yang menyaratkan tidak lebih dari 10, tapi ada juga yang menyaratkan tidak lebih dari 5) maka dapat dikatakan tidak terjadi multikolinieritas pada kedua variabel bebas tersebut. 


\section{Uji Heteroskredastisitas}

Tabel 3. Hasil Uji Heteroskedastisitas

Heteroskedasticity Test: Glejser

\begin{tabular}{llll}
\hline \hline F-statistic & 0.893401 & Prob. F(3,56) & 0.4503 \\
Obs*R-squared & 2.740483 & Prob. Chi-Square(3) & 0.4334 \\
Scaled explained SS & 2.157220 & Prob. Chi-Square(3) & 0.5404 \\
\hline \hline
\end{tabular}

Berdasarkan tabel bahwa nilai Prob. F hitung lebih besar dari tingkat alpha 0,05 (5\%) maka H0 diterima yang artinya tidak terjadi heteroskedastisitas, sedangkan apabila nilai Prob. F hitung lebih kecil dari dari tingkat alpha 0,05 (5\%) maka H0 ditolak yang artinya terjadi heteroskedastisitas dan jika nilai Prob. F hitung lebih besar dari dari tingkat alpha $0,05(5 \%)$ maka H0 diterima yang artinya terjadi tidak heteroskedastisitas. Nilai Prob. F hitung sebesar 0,4503 lebih besar dari tingkat alpha 0,05 (5\%) sehingga artinya terjadi tidak heteroskedastisitas.

\section{Uji Derajat Integritas}

Tabel 4. Uji Root Test- Augmented Dickey Fuller (DF) Pada 1st Different

\begin{tabular}{|c|c|c|c|c|}
\hline Variabel & $\begin{array}{c}\text { Nilai } \text { t } \\
\text { statistik ADF }\end{array}$ & $\begin{array}{c}\text { Test Critical } \\
\text { Values 5\% }\end{array}$ & Prob & $\begin{array}{c}\text { Kesimpula } \\
\text { n }\end{array}$ \\
\hline $\begin{array}{c}\text { Harga saham } \\
\text { syariah }\end{array}$ & $-7,376$ & $-2,912$ & 0,000 & Stasioner \\
\hline $\begin{array}{c}\text { Perubahan kurs } \\
\text { rupiah }\end{array}$ & $-8,879$ & $-2,912$ & 0,000 & Stasioner \\
\hline Laju inflasi & $-5,554$ & $-2,913$ & 0,000 & Stasioner \\
\hline $\begin{array}{c}\text { Fluktuasi kurs } \\
\text { valuta asing }\end{array}$ & $-8,316$ & $-2,914$ & 0,000 & Stasioner \\
\hline
\end{tabular}

Dari table diatas menunjukan bahwa setelah dilakukannya pengujian pada tingkat 1 st Diferent didapatkan hasil bahwa semuanya telah stasioner. Karena seluruh variabel stasioner pada tingkat difference pertama, maka pengujian ini dapat diteruskan ke dalam model Error Correction Model (ECM). 


\section{Pengujian Kointegritas}

Tabel 5. Pengujian Kontegritas

\begin{tabular}{ccccc}
\hline \hline $\begin{array}{c}\text { Hypothesized } \\
\text { No. of CE(s) }\end{array}$ & Eigenvalue & Statistic & Critical Value & Prob.** \\
\hline \hline None * & 0.589852 & 117.5720 & 69.81889 & 0.0000 \\
At most 1* & 0.405092 & 65.88027 & 47.85613 & 0.0004 \\
At most 2* & 0.264231 & 35.75806 & 29.79707 & 0.0091 \\
At most 3* & 0.204226 & 17.96138 & 15.49471 & 0.0208 \\
At most $4 *$ & 0.078027 & 4.711867 & 3.841466 & 0.0299 \\
\hline \hline
\end{tabular}

Berdasarkan tabel diatas menunjukan bahwa penggujian pada model johansen menunjukan bahwa terdapat 3 persamaan dalam penelitian ini yang terkoitegrasi pada taraf $5 \%(0,05)$. Hal ini dilihat saat nilai trace statistic lebih besar dari nilai critical value sehingga dapat disimpulkan bahwa penelitian ini terkontegrasi, maka hasil penelitian ini dapat dilanjutkan ke uji model jangka panjang dan error correction model (ECM).

\section{Pengujian Error Correction Model (ECM)}

Tabel 6. Pengujian Error Correction Model (ECM)

\begin{tabular}{ccccc}
\hline \hline Variable & Coefficient & Std. Error & t-Statistic & Prob. \\
\hline \hline LOGKURSRUPAIH & 0.018410 & 0.194642 & 0.094583 & 0.9250 \\
INFLASI & -0.001396 & 0.005610 & -0.248775 & 0.8045 \\
KURS_VALUTA_ASIN & & & & \\
G & 0.132817 & 0.310420 & 0.427864 & 0.6705 \\
C & -0.172072 & 1.860961 & -0.092464 & 0.9267 \\
RESID(-1) & -0.638930 & 0.143007 & -4.467832 & 0.0000 \\
RESID(-2) & -0.208709 & 0.143279 & -1.456661 & 0.1511 \\
\hline \hline
\end{tabular}

Dari persamaan diatas, dapat diketahui bahwa besarnya koefisien kointegritas yang berfungsi sebagai elemen penyesuaian (speed of adjustment) yakni ECT bernilai negatif sebesar -638930 dengan probabilitas sebesar $0,000<0,05$. Oleh karena itu pengujian ECM ini dapat dikatakan valid sehingga untuk pengujian hipotesis dipilih metode ECT (Error Correction Model). 


\section{Pembahasan Hasil Penelitian}

\section{Pengaruh Perubahan kurs rupiah Terhadap Harga Saham Syariah}

Tidak terdapat pengaruh dan signifikan variabel Perubahan kurs rupiah terhadap Harga saham syariah pada Perusahaan Yang Terdaftar di Bursa Efek Indonesia (BEI) periode 20152019. Dimana hasil menunjukan bahwa nilai sig 0,925 >0.05, dengan t-statistic sebesar 0,094. Artinya bahwa semakin tinggi perubahan kurs rupiah maka akan mengakibatkan semakin tingginya indeks harga saham pada perusahaan yang terdaftar di Bursa Efek Indonesia (BEI).

\section{Pengaruh Laju inflasi Terhadap Harga Saham Syariah}

Tidak terdapat pengaruh dan signifikan variabel Laju inflasi terhadap Harga saham syariah pada Perusahaan Yang Terdaftar di Bursa Efek Indonesia (BEI) periode 2015-2019. Dimana hasil menunjukan bahwa nilai sig 0,8045>0.05, dengan t-statistic sebesar 0,248775. Artinya bahwa semakin tinggi laju inflasi Indonesia tehadap USD maka akan mengakibatkan semakin tingginya indeks harga saham pada perusahaan yang terdaftar di bursa efek Indonesia (BEI).

\section{Pengaruh Pengaruh Fluktuasi Kurs Valuta Asing Terhadap Harga Saham Syariah}

Tidak terdapat pengaruh dan signifikan variabel Fluktuasi kurs valuta asing terhadap Harga saham syariah pada Perusahaan Yang Terdaftar di Bursa Efek Indonesia (BEI) periode 2015-2019. Dimana hasil menunjukan bahwa nilai sig 0,6705>0.05, dengan t-statistic sebesar 0,427864. Artinya bahwa semakin tinggi jumlah uang maka akan mengakibatkan semakin tingginya indeks harga saham pada perusahaan yang terdaftar di bursa efek Indonesia (BEI). Kurs valas dapat didefinisikan sebagai satuan valuta ( mata uang ) asing apabila ditukar dengan mata uang dalam negeri atau harga mata uang negara asing dalam satuan mata uang domestic.

\section{Pengaruh Perubahan kurs rupiah, Laju inflasi dan Fluktuasi kurs valuta asing Terhadap Harga Saham Syariah}

Terdapat pengaruh dan signifikan variabel Perubahan kurs rupiah, Laju inflasi dan Fluktuasi kurs valuta asing terhadap Harga saham syariah pada Perusahaan Yang Terdaftar di Bursa Efek Indonesia (BEI) periode 2015-2019. Dimana hasil menunjukan bahwa nilai sig $0,002956<0.05$, dengan F-statistic sebesar 4,151474. Artinya bahwa semakin tinggi perubahan kurs rupiah, laju inflasi dan fluktuasi kurs valuta asing maka akan mengakibatkan semakin tingginya indeks harga saham pada perusahaan yang terdaftar di bursa efek Indonesia (BEI).

\section{KESIMPULAN DAN SARAN}

1. Tidak terdapat pengaruh dan signifikan variabel Perubahan kurs rupiah terhadap Harga saham syariah pada Perusahaan Yang Terdaftar di Bursa Efek Indonesia (BEI) periode 2015-2019.

2. Tidak terdapat pengaruh dan signifikan variabel Laju inflasi terhadap Harga saham syariah pada Perusahaan Yang Terdaftar di Bursa Efek Indonesia (BEI) periode 20152019. 
3. Tidak terdapat pengaruh dan signifikan variabel Fluktuasi kurs valuta asing terhadap Harga saham syariah pada Perusahaan Yang Terdaftar di Bursa Efek Indonesia (BEI) periode 2015-2019.

4. Terdapat pengaruh dan signifikan variabel Perubahan kurs rupiah, Laju inflasi dan Fluktuasi kurs valuta asing terhadap Harga saham syariah pada Perusahaan Yang Terdaftar di Bursa Efek Indonesia (BEI) periode 2015-2019

\section{DAFTAR RUJUKAN}

Boediono, Fundamental Makro Ekonomi. Yogyakarta: Beta Offset Yogyakarta, 2012

Gujarati, Dasar - Dasar Ekonometrika, Edisi 5. Jakarta: Salemba empat, 2012.

I. Fahmi, Analisis Kinerja Keuangan. Bandung: Alfabeta, 2012.

Imam Ghozali, Aplikasi Analisis Multivariate dengan Program IBM spss 23. Semarang Badan Penerbit Universitas Diponegoro, 2015.

M. A. Putri and I. S. Wibisono, "Implementasi Neural Network Backpropagation Untuk Memprediksi Kurs Valuta Asing," J. Prodi Tek. Inform. UNW "Multimatrix," vol. II, no. 1, pp. 20-25, 2019.

M. Munir, "Analisis Pengaruh CAR, NPF, FDR dan Inflasi terhadap ProfitabilitasPerbankan Syariah di Indonesia,”. Econ. Financ. Bank., vol. 1, no. 1, p. 89, 2018

Muchtar E. H. and A. Nuruddin, "Evan Hamzah Muchtar, Amier Nuruddin, Saparuddin Siregar, 181,” J. Ekon. Islam, vol. 6, pp. 181-200, 2019.

S. A. Rifai, H. Susanti, and A. Setyaningrum, “Analisis Pengaruh Kurs Rupiah, Laju Inflasi, Jumlah Uang Beredar dan Pertumbuhan Ekspor terhadap Total Pembiayaan Perbankan Syariah dengan Dana Pihak Ketiga sebagai Variabel Moderating," MUQTASID J. Ekon. dan Perbank. Syariah, vol. 8, no. 1, p. 18, 2017, doi: 10.18326/muqtasid.v8i1.18-39.

Sadono Sukirno, Teori Pengantar Makroekonomi. Jakarta: PT Raja Grafindo Persada, 2015.

Sugiyono, Metode Penelitian Kuantitatif dan R \& D. Bandung: CV Alfabeta, 2017.

T. Gilarso, Pengantar Ilmu Ekonomi Mikro, Edisi Keli. Yogyakarta: Kanisius, 2008.

Yohanes Yahya2014, Pengantar Manajemen. Jakarta: Bumi Aksara. 